\title{
Wisdom
}

A short series of short pieces (with questions)

\section{Four Noble Truths}

A prince in Northern India in the 6th Century BC, was living in luxury, lacking nothing, until one day on his first expedition outside the palace he saw an old person, a man with a diseased body and a corpse. Carefully shielded previously, and confronted now for the first time with this undeniable evidence concerning life's reality and the apparently inevitable fate of mankind to suffer, he chose to leave his home, his lovely wife and young son in search of a solution, a way out of this pain-filled human predicament.

Six years later, it is told, at the age of 35 , this prince of the Sakya people, Gautama, attained Enlightenment. He has been known ever since as Buddha, "The Enlightened One". Living until he was 80, he spent the remainder of his life travelling around teaching all who came to him to learn. His "Way" he preached as open to all men and women ready to understand and to follow it.

The heart of the Buddha's teaching lies in Four Noble Truths, expounded in his very first sermon.

The First Noble Truth is dukkha which may be translated as "suffering" but also as "imperfection", "impermanence" or "insubstantiality". Dukkha may be viewed from three aspects: ordinary suffering '(such as old age, sickness, death; and to do with not having what one wants), suffering as a result of change (to do with losing what one has), and suffering as a conditioned state.

Of these conditioned states the Buddha taught, "Dukka is the five aggregates" (making up sentient beings, including man): the aggregates of matter, sensations, perceptions, mental formations and consciousness.

Many are surprised at how comprehensive and, to the Western mind, insightful, is Buddhist psychology based on an understanding of these five aggregates and the interplay between them.

The Second Noble Truth is samudaya, the origin of dukkha. This is the thirst or craving which, it is said, produces re-existence and re-becoming, which is bound up with passion and greed, which "finds fresh delight, now here and now there". The term includes not only attachment to (desire for) sense pleasures, wealth and power, but also attachment to ideas and ideals, views, opinions, theories, conceptions and beliefs.

The Third Noble Truth is nirodha, the cessation of dukkha. There is emancipation, freedom from the continuity of suffering. It is through the elimination of the thirst or craving of samudaya a modern commentator, Walpola Rahula, has said, "The one who has realised this Truth is the happiest being in the world, free from all the complexes and obsessions, the worries and troubles that torment others. This person's mental health is perfect. There is no repenting the past or brooding over the future. This being lives fully in the present, appreciating and enjoying things in the purest sense."

The Fourth Noble Truth is magga, "The Way Leading to the Cessation of Dukkha". It is known as "The Middle Way"; and also as, "The Noble Eightfold Path", because it is made up of the following eight categories: right understanding, right thought, right speech, right action, right livelihood, right effort, right mindfulness and right concentration.

Right speech, for example, means abstention from telling lies, from all negative comments, from backbiting and slander, from harsh or impolite language and from idle, useless chatter or gossip. It is based, we might say, on an unconditional positive regard for our environment and those in it.

The Buddha taught that the way of wisdom, the way of happiness, is also the way of virtue.

How can attachment, thirst and craving be eliminated?

Aldrington House

LARRY CULliford

Hove Community Mental Health Centre

Hove BN3 4AG

\section{Miscellany}

Mental Welfare Commission for Scotiand

Dr Alisdair A. McKechnie has been appointed ViceChairman of the Mental Welfare Commission for
Scotland in place of Dr W. D. Boyd who has recently retired. Dr James A. T. Dyer, formerly a consultant psychiatrist at the Royal Edinburgh Hospital, 